GRASAS Y ACEITES 68 (2)

April-June 2017, e189

ISSN-L: 0017-3495

doi: http://dx.doi.org/10.3989/gya.1057162

\title{
Effect of ultrasound on olive oil extraction and optimization of ultrasound-assisted extraction of extra virgin olive oil by response surface methodology (RSM)
}

\author{
A.Y. Aydar ${ }^{\mathrm{a}, \bowtie}$, N. Bağdatlı̆ğlu ${ }^{\mathrm{a}}$ and O. Köseoğlu ${ }^{\mathrm{b}}$ \\ ${ }^{a}$ Department of Food Engineering, Faculty of Engineering, Celal Bayar University. \\ Muradiye, Manisa 45140 Turkey \\ ${ }^{b}$ Ministry of Food, Agriculture and Livestock, Olive Research Station, İzmir, Turkey \\ ${ }^{\square}$ Corresponding author: alevyuksel.aydar@cbu.edu.tr
}

Submitted: 23 October 2016; Accepted: 06 February 2017

SUMMARY: In this study, the effects of different extraction parameters including ultrasound time, temperature and malaxation time on olive oil quality were investigated. The extraction variables ultrasound initial temperature $\left(20-50{ }^{\circ} \mathrm{C}\right)$, ultrasound time $(2-10 \mathrm{~min})$ and malaxation time $(30-50 \mathrm{~min})$ were studied to obtain ideal conditions of ultrasonic treatment on the olive paste for obtaining of a greater yield in the extraction of oil, while maintaining a maximum level of commercial quality. To evaluate the level of commercial quality, absorbance in the UV region, peroxide (PV) and free acidity values (AV), the total chlorophyll, carotenoid, phenol contents, total antioxidant activity and sensory analysis of EVOOs extracted from Edremit cultivar were determined. The optimum conditions were found to be $50{ }^{\circ} \mathrm{C}, 2 \mathrm{~min}$ and $43.23 \mathrm{~min}$ for ultrasound initial temperature, sonication time and malaxation time, respectively. This optimal condition gave an extraction yield of $8.25 \%$ and the acidity value of $0.24 \mathrm{mg}$ oleic acid/100 g olive oil. The experimental values obtained under optimal conditions were in agreement with the theoretical values

KEYWORDS: Extraction; Olive oil; Optimization; Quality; Ultrasound; Yield

RESUMEN: Efecto del ultrasonido en la extracción de aceite de oliva y optimización de la extracción asistida por ultrasonido del aceite de oliva virgen extra mediante metodología de superficie de respuesta (RSM). En este estudio se investigó el efecto de diferentes parámetros de extracción, incluyendo tiempo de ultrasonido, temperatura y tiempo de malaxación en la calidad del aceite de oliva. Se estudiaron las variables de la extracción como temperatura inicial de ultrasonido $\left(20-50^{\circ} \mathrm{C}\right)$, tiempo de ultrasonido $(2-10 \mathrm{~min})$ y tiempo de malaxación $(30-50 \mathrm{~min})$ para obtener las condiciones ideales del tratamiento ultrasónico en la pasta de oliva para obtener un mayor rendimiento en la extracción de aceite y manteniendo un máximo de calidad comercial. Para determinar el nivel de calidad comercial, se determinaron la absorbancia en la región UV, índice de peróxido (PV) y los valores de acidez libre (AV), contenido total de clorofila, carotenoides, fenoles, actividad antioxidante total y análisis sensorial de aceites de oliva extraídos del cultivar Edremit. Las condiciones óptimas fueron de $50^{\circ} \mathrm{C}, 2$ min y 43,23 min para temperatura inicial del ultrasonido, tiempo de sonicación y tiempo de malaxación, respectivamente. Estas condiciones óptimas dieron un rendimiento de extracción del 8,25\% y un valor de acidez de $0,24 \mathrm{mg}$ de ácido oleico/100 g de aceite de oliva. Los valores experimentales obtenidos en condiciones óptimas estuvieron de acuerdo con los valores teóricos.

PALABRAS CLAVE: Aceite de oliva; Calidad; Extracción; Optimización; Rendimiento; Ultrasonido

ORCID ID: Aydar AY http://orcid.org/0000-0001-9780-0917, Bağdatlığlu N http://orcid.org/0000-0003-4758-4472, Köseoğlu O http://orcid.org/0000-0002-3297-3355

Citation/Cómo citar este artículo: Aydar AY, Bağdatlığlu N, Köseoğlu O. 2017. Effect of ultrasound on olive oil extraction and optimization of ultrasound- assisted extraction of extra virgin olive oil by response surface methodology (RSM). Grasas Aceites 68 (2), e189. http://dx.doi.org/10.3989/gya.1057162

Copyright: (C2017 CSIC. This is an open-access article distributed under the terms of the Creative Commons Attribution (CC-by) Spain 3.0 License. 


\section{INTRODUCTION}

Virgin olive oil (VOO) is extracted from the olive fruits (Olea europaea L.) by using physical or mechanical processes and can be used without further treatments (Gómez-Rico et al., 2009; Montedoro and Servili, 1992). Olive oil extraction includes the crushing step which breaks up the cells of olive plant tissue so that oil droplets run out of mesocarp cells (Angerosa et al., 2001; Jiménez et al., 2007), the malaxation step contributes to the small oil droplets merging into large drops and the centrifugation step where oil is separated (Clodoveo and Hachicha Hbaieb, 2013). Malaxation is a low (20-30 rpm) and continuous kneading of olive pastes (Clodoveo, 2012), and influences the oil quality and the optimal extraction yield (Puértolas and Martínez de Marañón, 2015). A greater amount of oil was obtained by increasing the malaxation time and/ or temperature (Ben Brahim et al., 2015; Taticchi et al., 2013). However, applying long malaxation times and high temperatures in olive oil extraction can cause a deterioration in oil quality and reduce the oxidative stability of olive oil (Di Giovacchino et al., 2002; Taticchi et al., 2013) due to the activity of the enzymes (polyphenol oxidase and peroxidase), naturally present in the olive paste, which may affect the percentage of free fatty acid content, peroxide value and phenol content of the oil (De Fernandez et al., 2014; Franco et al., 2014; Stefanoudaki et al., 2011; Taticchi et al., 2013). Therefore, finding innovative techniques to eliminate residues of oil in the pomace, thus improving the yield and the working capacity of the industrial plants has become significant for many researchers (Abenoza et al., 2013; Clodoveo and Hachicha Hbaieb, 2013; Jiménez et al., 2007; Puértolas and Martínez de Marañón, 2015).

Ultrasound, a novel technology, has been applied in several operations in food science (Kadam et al., 2015; Samaram et al., 2015). Recently, ultrasound treatment during olive oil extraction has been studied by several researchers (Bejaoui et al., 2016, 2015; Clodoveo and Hachicha Hbaieb, 2013; Clodoveo, 2012; Clodoveo et al., 2013b; Jiménez et al., 2007; Jiménez Márquez et al., 2006). Although these authors studied the ultrasound as a part of malaxation, the optimal conditions of ultrasound temperature, ultrasound time and malaxation time for an ultrasound assisted extraction of extra virgin olive oil were unknown.

The amount of olive oil extracted from olives is influenced by the extraction temperature and time, which reflects the conflicting action of degradation by oxidation (Di Giovacchino et al., 2002; Taticchi et al., 2013). Therefore, it is of importance to select an efficient extraction procedure and to maintain the stability of antioxidant compounds and qualitative properties of olive oil (Clodoveo et al., 2013a). In order to optimize the extraction conditions when using ultrasound for the extraction of olive oil, including ultrasound temperature, sonication time and malaxation time, the response surface methodology (RSM) has been used.

Previous research focused on the determination of the effects of ultrasound extraction parameters including ultrasound time and temperature on the yield and quality characteristics of olive oil from different olive cultivars including Picual and Coratina (Bejaoui et al., 2015; Clodoveo et al., 2013a; Jiménez et al., 2007). However, to the best of our knowledge, there is no published study addressing the optimum ultrasound assisted extraction conditions and evaluating the potential benefit of the application of ultrasound adapted in the malaxation step on improving the actual extraction process of virgin olive oil without applying any pre-heating or heating stage. Therefore, the aims of this work were to gain a better understanding of the mechanism of ultrasonication and determine the optimal condition to extract the extra virgin olive oil of the Edremit cultivar, by means of the employment of ultrasound, improving the oil yield and preserving its quality.

\section{MATERIALS AND METHODS}

\subsection{Olive Fruit Samples}

Olive fruits (Olea europaea L.) from the Edremit cultivar grown in the Mut area were harvested in the 2015 crop season. Olives with a maturity index of 3.35 were picked at their early ripening stage in October. The maturity index was calculated according to the method of the International Olive Oil Council (IOOC, 2011). According to this method, 100 fruits were randomly taken to assess their level of maturity by a subjective evaluation of the color of the olive skin and flesh. Then the olives were distributed into eight groups, according to the following characteristics: bright-green skin (group $\mathrm{N}=0$ ), greenish-yellowish skin (group $\mathrm{N}=1$ ), green skin with reddish spots (group $\mathrm{N}=2$ ), reddish-brown skin (group $\mathrm{N}=3$ ), black skin with white flesh (group $\mathrm{N}=4$ ), black skin with $<50 \%$ purple flesh (group $\mathrm{N}=5$ ), black skin with $>50 \%$ and $<100 \%$ purple flesh (group $\mathrm{N}=6$ ), and black skin with $100 \%$ purple flesh (group $\mathrm{N}=7$ ). Maturation indexes ranged from 0 (intense green skin) to 7 (black skin and 100\% purple flesh). The maturity index was calculated by $\Sigma\left(\mathrm{N}_{\mathrm{i}} \mathrm{n}_{\mathrm{i}}\right) / 100$, where $\mathrm{N}$ is the group number and $\mathrm{n}$ is the olive amount in that group (Espínola et al., 2009).

The olives were put in $25 \mathrm{~kg}$ boxes and brought to the pilot plant. The total oil content (TOC) and moisture content of the olive samples were determined. Moisture content ( $\%$ weight/weight) was determined at $120{ }^{\circ} \mathrm{C}$ to its constant weight and TOC (\% weight / weight) of the olive samples was determined using Soxhlet extraction. 


\subsection{Ultrasound Assisted Olive Oil Extraction}

A laboratory mill, equipped with a mixer, a basket centrifuge and a metal crusher was used to extract oil from olive fruits. After the washing process, the olives were crushed and the olive pastes ( $2 \mathrm{~kg}$ each) were sonicated from 2 to 10 minutes and then malaxated for 30 to 50 minutes. The ultrasound system used in this study was ultrasonic bath $(150 \mathrm{~kW}$ and ultrasonic frequency $37 \pm 2 \mathrm{KHz}$; Tank volume $4 \mathrm{~L}$ ). Each olive paste sample was centrifuged for 1 minute and the oil was collected in $500 \mathrm{ml}$ dark colored bottles. No co-adjuvant or preheating process was applied during extraction and all experiments were performed in triplicate.

\subsection{Temperature Measurement}

The temperature measurements were taken by a $\mathrm{K}$ type thermocouple by placing the 3 probes at different points of the ultrasound tank for every 30 seconds. The ultrasound tank and the laboratory mill, equipped with a mixer, a basket centrifuge and a crusher were subjected to the cleaning process with water before and after every measurement to avoid contamination which can affect the accuracy of extraction yield and quality characteristic measurements. After cleaning all parts of the extraction unit with water, a thorough drying of the unit was carried out.

\subsection{Yield}

Extraction yield was defined as the percentage of the extracted olive oil from the total weight of the fruit $(\mathrm{g})$. The extraction yield was calculated using the formula below:

Yield $=\frac{\text { Extracted Oil }(g)}{\text { Olive Fruit }(g)} \times 100$

\subsection{Qualitative, nutritional and sensory characteristics of olive oil}

The ultra-violet absorptions (K232 and K270), the olive oil free acidity ( $\%$ oleic acid per $100 \mathrm{~g}$ of olive oil) and peroxide value $\left(\mathrm{mEq} \mathrm{O}_{2} / \mathrm{kg}\right.$ oil) were used for evaluating the qualitative properties of the oils (European Union Commission Regulation, 1991), whereas the total chlorophyll, total carotenoid, total phenol content and total antioxidant activity (DPPH assay) analyses were used to determine the nutritional characteristics of the oils.

The chlorophyll and carotenoid contents were determined colorimetrically at 670 and $470 \mathrm{~nm}$, respectively, and the results were expressed as $\mathrm{mg} / \mathrm{kg}$ (Gandul-Rojas and Mínguez-Mosquera, 1996).

Chlorophyll $=\left(\mathrm{A}_{670} \times 10^{6}\right) /(613 \times 100 \mathrm{xd})$

$$
\text { Carotenoid }=\left(\mathrm{A}_{470} \times 10^{6}\right) /(2000 \times 100 \times \mathrm{d})
$$

where $\mathrm{A}$ is the absorbance and $\mathrm{d}$ is the spectrophotometer cell thickness $(1 \mathrm{~cm})$.

Phenols were extracted from the olive oil by liquidliquid extraction using methanol as solvent and the concentration was measured using the Folin-Ciocalteau reagent at $725 \mathrm{~nm}$. The total phenolic content was expressed as $\mathrm{mg}$ of gallic acid equivalents per $\mathrm{kg}$ of extra virgin olive oil (Montedoro and Servili, 1992).

The antioxidant activity was determined by the 1,1-diphenyl-2-picryl hydrazyl (DPPH) radical scavenging activity according to the method of (Sevim et al., 2013) with some modifications. $1 \mathrm{~g}$ of oil was dissolved in $5 \mathrm{~mL}$ methanol and then shaken for $5 \mathrm{~min}$ with a homogenizer. The solution centrifuged at 3500 $\mathrm{rpm}$ for $10 \mathrm{~min}$ in order to separate non-polar and polar compounds. DPPH radical scavenging activity determination was carried out at the methanol phase. The extracts $(100 \mu \mathrm{L})$ were gently mixed with methanol $(1,900 \mu \mathrm{L})$ and a $100 \mathrm{mM}$ DPPH solution $(1,900 \mu \mathrm{L})$ for blanks and allowed to stand in the dark for $15 \mathrm{~min}$ at $25^{\circ} \mathrm{C}$. A spectrophotometer (Shimadzu Spectrophotometer UV- 1700 PharmaSpec, Japan) was used to read the absorbance of the resultant solution at $517 \mathrm{~nm}$ against a blank sample without DPPH. The Trolox equivalent (TE) of the DPPH radical scavenging activity quantification was determined against a minimum of a five-point calibration curve prepared with known concentrations of Trolox (Sigma-Aldrich Co. LLC, St. Louis, MO, USA). The results were expressed as $\mu \mathrm{mol}$ TE of $100 \mathrm{~g}$ of each sample based on a calibration curve $\left(\mathrm{R}^{2}=0.998\right)$.

To determine the long term effects of ultrasound, the olive oils were stored at room temperature for 12 months. A sensory analysis was conducted by a panel test according to the method of Achat et al. (2002). The sensory quality of the oil samples were evaluated by 10 trained panellists. The panelists evaluated the overall acceptability of each oil sample (taking into account any positive and negative taste), using a numerical scale 1-5 (1 = not acceptable, 5 = extremely good), as well as bitterness and fruity etc. ( $1=$ no bitterness, $5=$ extremely bitter $)$. EVOO classification establishes a mean value of the defects of 0 and a mean value for fruity above 0 according to EU legislation (Achat et al., 2012; Puértolas and Martínez de Marañón, 2015).

\subsection{Experimental Design}

A three-level, three-factor, Box-Behnken Design (BBD) was applied to generate a total of 17 experiments for the optimization of ultrasound assisted extraction parameters and to evaluate the combined effects of three independent variables. The ultrasound time (2-10 min.), ultrasound initial temperature (20$\left.50{ }^{\circ} \mathrm{C}\right)$, and malaxation time $(30-50 \mathrm{~min}$.) were the parameters and levels employed. The original values 
TABLE 1. Variables and their Levels in Response Surface Design

\begin{tabular}{lcccc}
\hline & & \multicolumn{4}{c}{ Coded Levels } \\
\cline { 3 - 5 } Independent variables & Symbols & $\mathbf{- 1}$ & $\mathbf{0}$ & $\mathbf{1}$ \\
\hline Ultrasound time (min.) & $\mathrm{X}_{1}$ & 2 & 6 & 10 \\
Ultrasound initial & $\mathrm{X}_{2}$ & 20 & 35 & 50 \\
temperature $\left({ }^{\circ} \mathrm{C}\right)$ & & & & \\
Malaxation time (min.) & $\mathrm{X}_{3}$ & 30 & 40 & 50 \\
\hline
\end{tabular}

and the coded values of independent parameters which were based on the results of our preliminary study are illustrated in Table 1. In order to evaluate the pure error and the curvature the complete design consisted of 17 combinations with 5 replicates of the center point.

\subsection{Statistical Analysis}

The effects of different ultrasound parameters on the qualitative and nutritional parameters of olive oils one way ANOVA were tested on all individual data groups to determine the significant differences using SAS 9.2 (SAS Institute Inc., Cary, NC, 2009). A Tukey's multiple comparison tests, at $\mathrm{p}<0.05$, was applied to determine differences among data groups. Correlation coefficients between instrumental results were also determined using SAS.

For the optimization part of this study, DesignExpert version 8.0 (Stat-Ease, Minneapolis, MN) was used to analysis of variance (ANOVA) tables and the regression coefficients of individual linear, quadratic and interaction terms. The experimental data were evaluated to fit a statistical model (Linear, Quadratic, Cubic or 2FI). The coefficients of the model were represented by constant terms, A, B and C (linear coefficients for ultrasound time, ultrasound temperature and malaxation time, respectively), $\mathrm{AB}, \mathrm{AC}$ and $\mathrm{BC}$ (interactive term coefficient), $\mathrm{A}^{2}, \mathrm{~B}^{2}$ and $\mathrm{C}^{2}$ (quadratic term coefficient). Correlation coefficient $\left(\mathrm{R}^{2}\right)$, adjusted determination coefficient $\left(\mathrm{Adj}-\mathrm{R}^{2}\right)$ and adequate precision were used to check the model adequacies; the model was adequate when its $P$ value $<0.05$, lack of fit $P$ value $>0.05, R^{2}>0.9$ and Adeq Precision $>4$. Differences among means were tested for statistical significance using analysis of variance (ANOVA). The statistical significance level was set at $\mathrm{P}<0.05$.

\section{RESULTS AND DISCUSSION}

\subsection{Effect of different ultrasound parameters on extraction yield, quality, sensorial and nutritional parameters of olive oil}

\subsubsection{Extraction yield}

In olive oil extraction, some part of the oil cannot be released since it is emulsified with olive mill waste water and left with the olive pomace (Boskou, 2007). Therefore, oil (20-25\%) remains in the mesocarp cell even after centrifugation (Aguilera et al., 2010). The impact of ultrasound on oil extraction could be explained by the cell membrane disruption and the consequent improving of mass transfer phenomena (Achat et al., 2012). Ultrasound assists in the release of oil from the mesocarp cells that have not been disrupted by crushing (Puértolas and Martínez de Marañón, 2015). Extraction yield is accepted as one of the main parameters determining the efficiency of olive oil extraction.

This parameter indirectly takes into account the oil content held in vegetable water and pomace (Angerosa et al., 2001; Puértolas and Martínez de Marañón, 2015).

The moisture and fat content of olives used in this study were $43.57 \%$ and $17.87 \%$, respectively. Table 2 shows the EVOO yields obtained by different ultrasound parameters. The highest yields at $8.25 \%$ and $8.10 \%$ were observed when olive pastes were subjected to $10 \mathrm{~min}$ of ultrasound at $35^{\circ} \mathrm{C}$ and 50 min of malaxation and 2 min of ultrasound at $35^{\circ} \mathrm{C}$ and $50 \mathrm{~min}$ of malaxation, respectively. This result can be explained by the fact that this highest malaxation time (50 minute) among all treatments allowed the oil droplets to liberate from the oleosomes of the mesocarp cells of olive fruits and the ultrasound time applied in extraction did not affect the oil yield $(p>0.05)$ at $.3 .60 \%$, which was the lowest yield among all treatments and was obtained by $2 \mathrm{~min}$ of ultrasound at $20^{\circ} \mathrm{C}$ and $40 \mathrm{~min}$ of malaxation. These results were similar to those observed in previous studies (Bejaoui etal., 2015; Clodoveo et al., 2013a; Jiménez et al., 2007). Clodoveo et al. (2013a) reported a significant increase of $0.70 \%$ and $1.00 \%$ in 'Coratina' oil yield, for $4 \mathrm{~min}$. or $8 \mathrm{~min}$. ultrasound treatment $(35 \mathrm{kHz} ; 150 \mathrm{~W})$ of olive pastes, respectively, with a subsequent pre-heating (19 minutes and 8 minutes) and a malaxation step of $30 \mathrm{~min}$ at $30^{\circ} \mathrm{C}$. Jiménez et al., (2007) found that no significant increase was observed in the yield efficiency of 'Picual' olive oils obtained by indirect sonication with an ultrasound-cleaning bath $(150 \mathrm{~W}$ and $25 \mathrm{kHz}$ ) compared to oils extracted without any ultrasound treatment. It can be concluded that olive variety, extraction type (conventional, ultrasound or microwave assisted, etc.) and extraction conditions (time, temperature, pre-heating and/or co-adjuvant utilization) have crucial effects on ultrasound extraction efficiency.

\subsubsection{Qualitative properties}

In our study no pre-heating process was applied to olive pastes which could contribute to not only increase the quantity of the extracted EVOO but also to increase its acidity. The results for free acidity, peroxide number and UV absorptions are shown in 
TABLE 2. Design and Results of Box-Behnken Experiments

\begin{tabular}{lccccc}
\hline Runs & $\mathbf{X}_{\mathbf{1}}$ & $\mathbf{X}_{\mathbf{2}}$ & $\mathbf{X}_{\mathbf{3}}$ & Yield (\%) & $\begin{array}{c}\text { AV } \\
\text { (g oleic acid/100 g oil) }\end{array}$ \\
\hline 1 & 0 & 0 & 0 & 7.20 & 0.40 \\
2 & 0 & 1 & -1 & 5.65 & 0.50 \\
3 & -1 & 1 & 0 & 7.90 & 0.25 \\
4 & 0 & 0 & 0 & 7.50 & 0.45 \\
5 & 0 & 1 & 1 & 8.00 & 0.38 \\
6 & 1 & 0 & 1 & 8.25 & 0.41 \\
7 & 0 & 0 & 0 & 7.45 & 0.40 \\
8 & 1 & -1 & 1 & 6.00 & 0.22 \\
9 & -1 & 0 & 1 & 8.10 & 0.46 \\
10 & 0 & -1 & 0 & 5.60 & 0.33 \\
11 & 1 & 1 & 5.90 & 0.45 \\
12 & 0 & -1 & -1 & 5.00 & 0.20 \\
13 & -1 & 0 & -1 & 3.60 & 0.32 \\
14 & 1 & -1 & 5.50 & 0.43 \\
16 & -1 & 0 & 0 & 6.70 & 0.35 \\
17 & 0 & 0 & 0 & 7.50 & 0.41 \\
\hline
\end{tabular}

AV. Acidity value; $\mathrm{X}_{1}$ : Ultrasound time; $\mathrm{X}_{2}$ : Ultrasound initial temperature; $\mathrm{X}_{3}$ : Malaxation time.

Table 3 . The acidity values of samples were between 0.20 and $0.50 \%$ oleic acid. The peroxide values (PV) ranged from 3.26 to 7.33 meq $\mathrm{O}_{2} / \mathrm{kg}$ oil where all samples had values below $20 \mathrm{mEq} \mathrm{O}_{2} / \mathrm{kg}$ oil, the acceptable limit of the IOOC (International Olive Oil Council, 2003). The peroxide values of the oils subjected to the highest sonication temperatures were slightly higher than those obtained at lower ultrasound temperatures. The relatively higher values in $\mathrm{AV}$ and PV of oils found in this study compared to those reported by previous researchers (Bejaouiet al., 2015; Clodoveo et al., 2013a, 2013b; Fiori et al., 2014; Jiménez et al., 2007) might be due to different extraction conditions such as higher sonication temperatures and longer malaxation times.

K232 is related to the primary oxidation of oil and the conjugation of polyunsaturated fatty acids and K270 is related to secondary oxidation products of oils and it is an indication of aldehydes, ketones and carbonyl compounds (Boskou, 2007). The ultra violet (UV) absorption values at K232 and $\mathrm{K} 270$, ranged from 1.345 to 1.453 and 0.076 to 0.120 , respectively. According to the AV, PV and UV results, all oil samples were classified as extra virgin olive oil by the IOOC (International Olive Oil Council, 2003). These are similar to the results presented by previous researchers (Bejaoui et al., 2015; Clodoveo et al., 2013a; Jiménez et al., 2007), as they also observed that all oils obtained by ultrasound were classified as extra virgin olive oil. Significant diferences were found between treatments for both UV absorbance at $270 \mathrm{~nm}$ and $232 \mathrm{~nm}(\mathrm{p}<0.05)$.
This could be a consequence of different temperatures and times applied to the olive pastes. In general, for quality parameters, olive oils obtained by 2-minute ultrasound showed the lowest values for K232 and K270.

\subsubsection{Nutritional and sensorial properties}

Chlorophyll is the characteristic green pigment of olive oil which determines the color intensity. The degree of green color of the olive oil is dependent on chlorophyll and carotenoid contents. The pigment concentration of oils differs greatly depending on the variety and degree of ripeness of the fruit. When the oil is exposed to light, it is rapidly oxidized because chlorophyll acts as a pro-oxidant. Therefore, early harvest oils must be stored in the dark, such as in a green bottle, in order to preserve their quality (Angerosa et al., 2001; Gandul-Rojas and MínguezMosquera, 1996). The total chlorophyll contents in samples were between $3.65 \mathrm{mg} / \mathrm{kg}$ and $8.52 \mathrm{mg} / \mathrm{kg}$ and the total carotenoid content ranged from $2.87 \mathrm{mg} / \mathrm{kg}$ and $5.12 \mathrm{mg} / \mathrm{kg}$. When $2 \mathrm{~min}$ ultrasound was applied to olives pastes, both carotenoid and chlorophyll contents were lowest; whereas they were highest when olive pastes were subjected to $6 \mathrm{~min}$ ultrasound (Table 3). However, carotenoid and chlorophyll contents were lower in oils extracted by 10 minute sonication than oils extracted by 6 minute ultrasound. This can be explained by the fact that initially the total chlorophyll and carotenoid compounds increased up (or achieved) to a maximum 


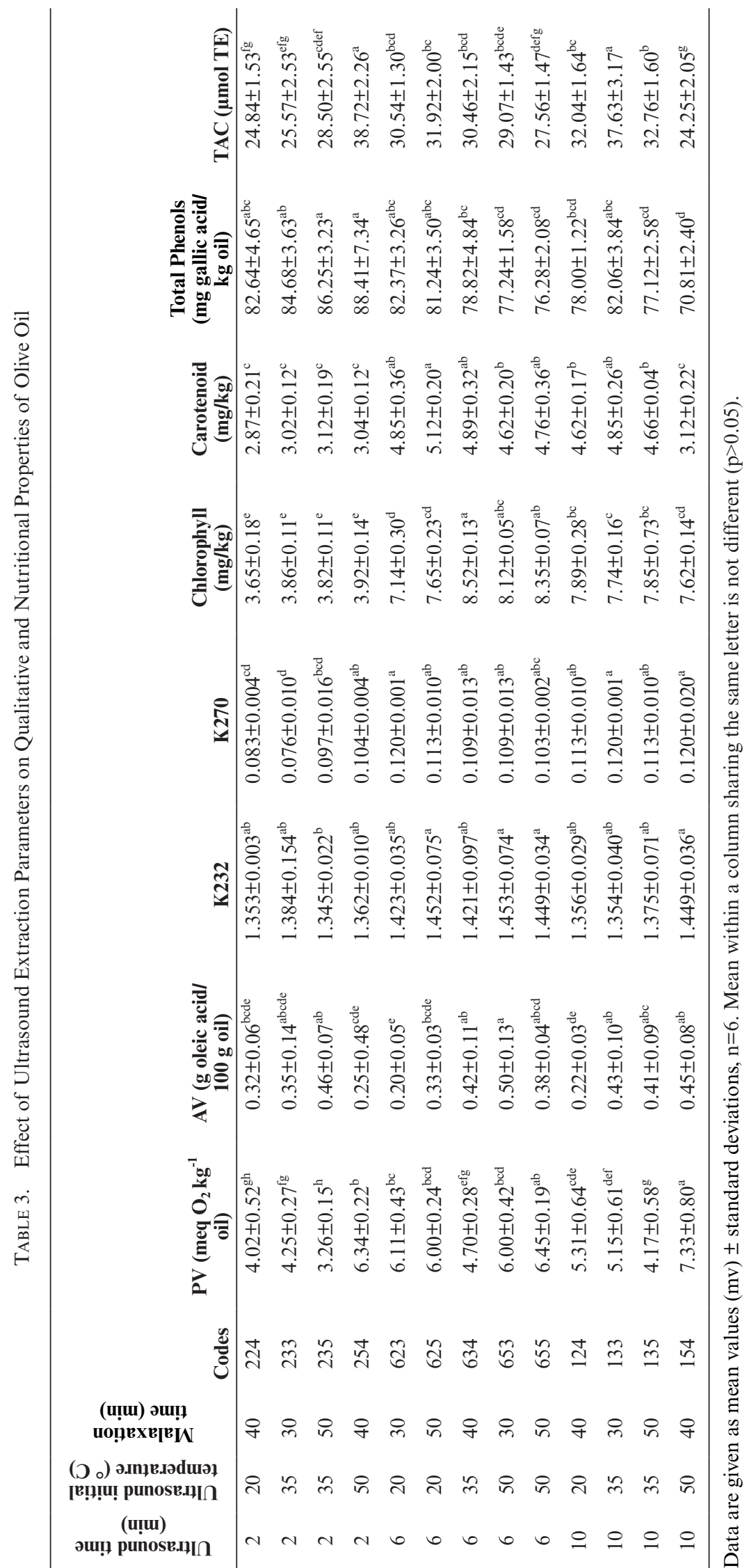


value because of the cavitation phenomena, and then these minor compounds decreased as the duration of sonication and temperature increased.

Phenolic compounds are important bioactive components in olive oil that protect it against oxidation (Montedoro and Servili, 1992). The highest and lowest total phenol contents of the oils were obtained at $88.41 \mathrm{mg} / \mathrm{kg}$ and $70.81 \mathrm{mg} / \mathrm{kg}$, for 254 and 154 samples, respectively. The total phenol content decreased as the duration of ultrasound treatment on olive paste was extended. This observation can be explained by the presence of oxygen, which acts as a cofactor in many enzymatic reactions and as a promoter of non-enzymatic oxidations. When the olive pastes were submerged in an ultrasound, both enzymes (polyphenol oxidase, peroxidase) and substrates (phenols) were released, which could contribute to oxidation. The differences in the amount of phenolic content of olive oils compared to previous studies was probably due to a range of factors affecting total phenolic compounds such as maturity level, cultivar, climate and extraction method. The antioxidant activity of olive oils extracted at different parameters varied from 24.25 to 38.72 $\mu \mathrm{mol}$ trolox equivalent in our study. The differences among the antioxidant activities of the olive oils could be due to the types of antioxidants which are recovered at different stages of extraction. Oils subjected to 10 min ultrasound at the highest ultrasound temperature and highest malaxation time had the lowest phenolic content and total antioxidant activity with a highest peroxide value and a relatively high acidity. It can be concluded that the application of ultrasound at high temperatures for long periods has an adverse effect on the oil quality.

Figure 1 shows the intensity attributes evaluated by panelists. The panelists perceived no negative attributes such as rancid or musty-humid taste. The oils coded as 133 and 254 were evaluated to be fruitier than other oils; although pungent and bitter properties in the oils were not significantly different. The oils extracted by $10 \mathrm{~min}$ ultrasound at $50^{\circ} \mathrm{C}$ and
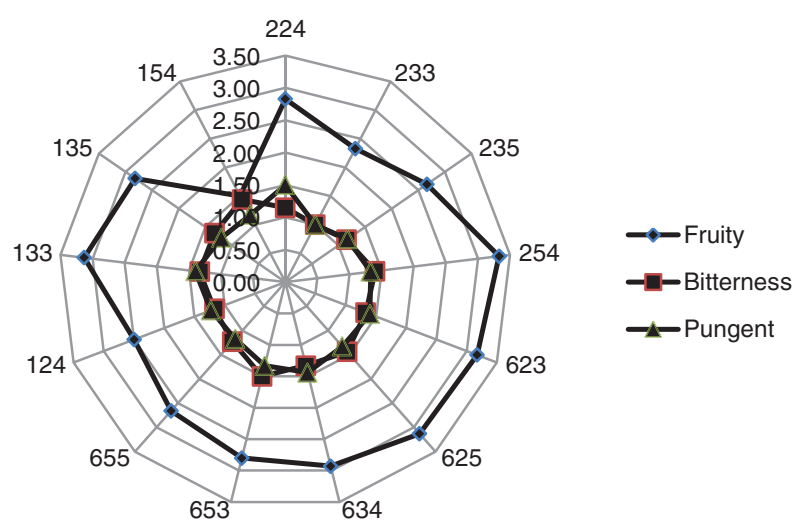

Figure 1. Sensorial properties of olive oil after 12 months' storage.
40 min of malaxation (sample: 154) were evaluated at the lowest fruity scale for oils. After 12 months' storage of the olive oils at room temperature, all the olive oils extracted by ultrasound showed sensory profiles belonging to the EVOO category. Therefore, it can be concluded that ultrasound had a positive effect on the sensory properties of the oil not only after extraction but also after long term storage. Jimenez et al. (2007) did not find any defect associated with ultrasound on olive oil production either.

\subsection{Fitting the response surface methods}

In order to achieve the lowest acidity and the highest yield, the Box-Behnken design was used to optimize extraction parameters including ultrasound time, ultrasound temperature and malaxation time (Table 2). For the three factors, the Box-Behnken design was chosen since it offers advantages in requiring a fewer number of runs. Results showed that the yield ranged from 3.60 to $8.25 \%$ and the maximum extraction yield of olive oil from ultrasound assisted extraction was obtained at higher temperatures and longer malaxation times as reported by several researchers (Angerosa et al., 2001; Inarejos-García et al., 2009; Samaram et al., 2015; Taticchi et al., 2013). These values were relatively lower than the values reported by Clodoveo et al., (2013) and Jimenez et al., (2007). This difference for yield could be related to different varieties of olives and the pre-treatments like heat treatment used in previous studies.

To show the significant $(p<0.05)$ interaction effects of ultrasound extraction parameters on the yield (Fig. 2a-c) and acidity value (Fig. 2d-f) 3D response surface plots were created. According to the results, a higher amount of oil was obtained by the ultrasound extraction at elevated ultrasound temperatures for longer malaxation time which could confirm that the ultrasound extraction at higher temperatures could disintegrate the cell wall and membranes, and promote the mass transfer from olive fruit (Samaram et al., 2015). However, the ultrasound time applied in the extraction had no significant effect on the yield (Figures2a and $2 b$ ). The ultrasound extraction at higher temperatures with longer sonication times resulted in higher acidity (Figure 2d).

The $\mathrm{P}$ value, $\mathrm{F}$ value, $\mathrm{R}^{2}$, Adj- $\mathrm{R}^{2}$ and Adeq. Precision estimate of the adequacy of each model is shown in Table 4. High F values (27.90 for yield, 11.16 for $\mathrm{AV}$ ) and low $\mathrm{P}$ values (0.0001 and 0.0022 , for yield and $\mathrm{AV}$, respectively), indicated that the models were highly significant for yield and AV. The $\mathrm{R}^{2}$ of the predicted models for the yield and AV in olive oil extraction were 0.9729 and 0.9349 , respectively. Adj. $\mathrm{R}^{2}$ values were 0.9380 and 0.8511 for yield and $\mathrm{AV}$, respectively, which indicated a high degree of linear fit between the predicted and experimental values. The lack-of-fit test showed the 

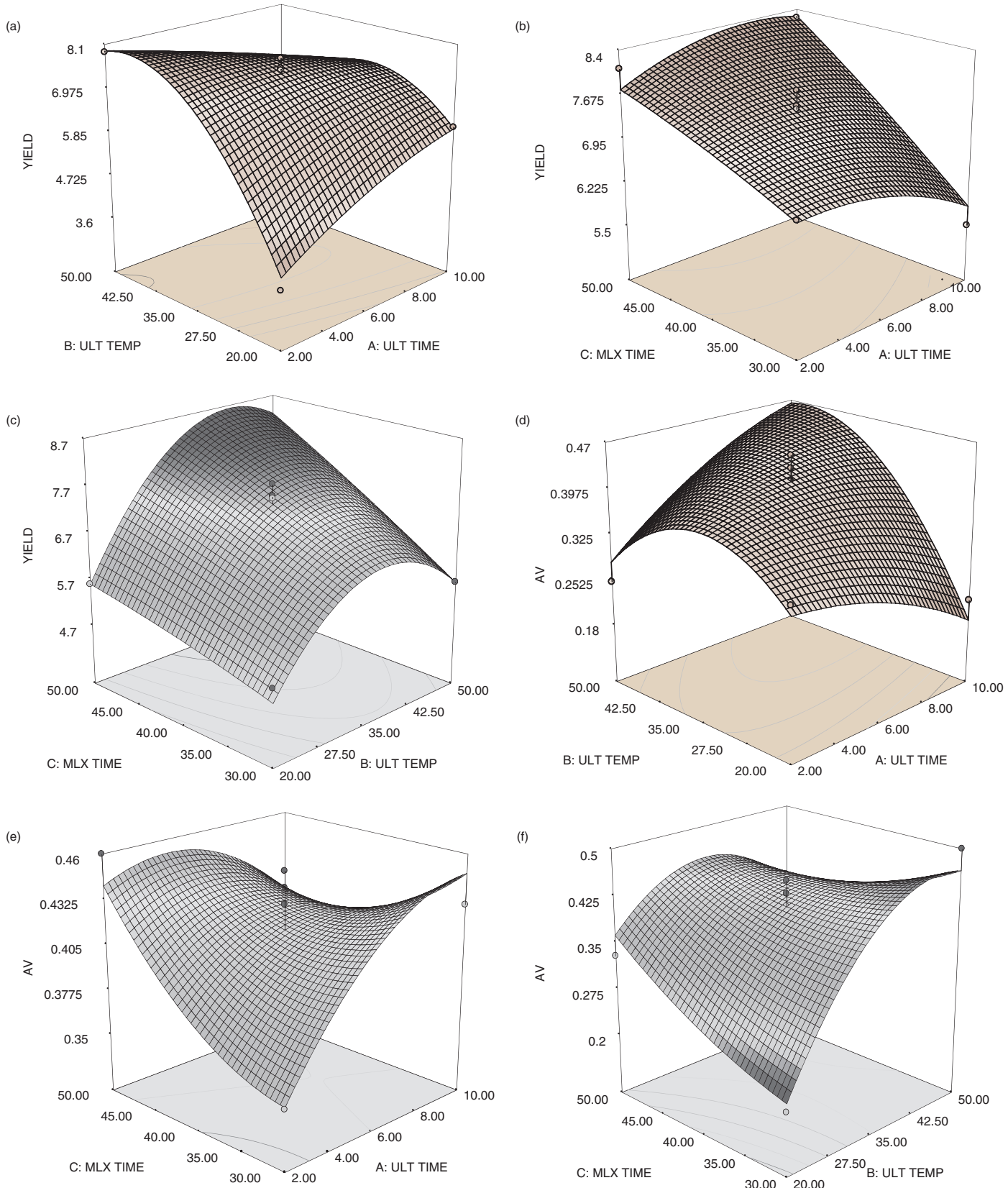

Figure 2. Response Surface Plots for the Yield (a,b,c) and the Acidity Value (d,e,f).

fitness of the model. The $\mathrm{P}$ value of 0.0705 for the yield and 0.0996 for AV indicated that the models fit the experimental data accurately. These results indicate that the models for AV and the yield were adequate for predicting within the range of the variables employed. The coefficients of the variables in the regression models for the yield and AV and their significance are shown in Table 5.

The free acidity value of olive oil is considered to be a significant factor which determines the quality of oil. The acidity of the oils for all experiments was below the legal limit $(<8$ g oleic acid/kg oil) established for the category of EVOO (European Union Commission Regulation, 1991). The low acidity levels found after sonication were presumably associated with a high quality of olive fruits and appropriate storage conditions of the oil until analysis. In terms of $\mathrm{AV}$, the independent variable $(B)$, the quadratic term $\left(\mathrm{B}^{2}\right)$ and the interactive terms $(\mathrm{AB}, \mathrm{BC})$ were all significant 
TABLE 4. ANOVA for Examination of Every Regression Model Adequacy

\begin{tabular}{|c|c|c|c|c|c|c|c|}
\hline \multirow[b]{2}{*}{ Responses } & \multicolumn{2}{|c|}{ Model } & \multirow[b]{2}{*}{$\mathbf{R}^{2}$} & \multirow[b]{2}{*}{ Adj- $R^{2}$} & \multirow[b]{2}{*}{ Adeq. Precision } & \multicolumn{2}{|c|}{ Lack of Fit } \\
\hline & F Value & P Value & & & & SS & P Value \\
\hline Yield & 27.90 & $0.0001^{*}$ & 0.97 & 0.94 & 17.27 & 0.61 & $0.07 * *$ \\
\hline AV & 11.16 & $0.002^{*}$ & 0.93 & 0.85 & 10.88 & 0.0005 & $0.10 * *$ \\
\hline
\end{tabular}

Adj- $\mathrm{R}^{2}$. adjusted determination coefficient; SS. Sum of square. PV. Peroxide value; AV. Acidity value;

TAC. Total antioxidant capacity; *. significant; **. non significant.

TABle 5. Coefficients of the Variables in the Regression Models and their Significance

\begin{tabular}{lll}
\hline Coefficients & Yield & AV \\
\hline Constant & 7.48 & 0.418 \\
A & -0.08125 & 0.01625 \\
B & $0.90625^{*}$ & $0.06375^{*}$ \\
C & $0.8875^{*}$ & 0.0125 \\
AB & $-1.1^{*}$ & $0.075^{*}$ \\
AC & 0.3375 & -0.0325 \\
B C & $0.4375^{*}$ & $-0.0625^{*}$ \\
A $^{2}$ & -0.2775 & -0.024 \\
B $^{2}$ & $-1.3525^{*}$ & $-0.084^{*}$ \\
C $^{2}$ & -0.065 & 0.0185 \\
\hline
\end{tabular}

*. significant at $5 \%$ level.

$(\mathrm{P}<0.05)$. The quadratic regression model for $\mathrm{AV}$ was as follows:

$$
\mathrm{AV}=0.418+0.06375 \mathrm{~B}+0.075 \mathrm{AB}-0.0625 \mathrm{BC}-0.084 \mathrm{~B}^{2}
$$

In terms of yield, the independent variables (B, $\mathrm{C})$, the quadratic term $\left(\mathrm{B}^{2}\right)$ and the interactive terms $(\mathrm{AB}, \mathrm{BC})$ were all significant $(\mathrm{P}<0.05)$. The quadratic regression model for yield is given below:

Yield $=7.48+0.90625 \mathrm{~B}+0.8875 \mathrm{C}-1.1 \mathrm{AB}+0.4375 \mathrm{BC}-1.3525 \mathrm{~B}^{2}$

The most significant effect on the extraction yield and the acidity $(\mathrm{p}<0.05)$ was the malaxation temperature among all ultrasound extraction variables. Conversely, ultrasound time showed no effect $(p>0.05)$ on the yield and the acidity.

\subsection{Optimization of the extraction process and the validation of the model}

In order to optimize the UAE variables which resulted in the most desirable responses numerical optimizations were applied. The purpose of this study was to improve the oil extraction resulting in the highest yield and the lowest acidity. The interaction effects of ultrasound extraction variables on the yield and acidity of olive oil are shown in 3D surface plots (Figure 2a-c and Figure 2d-f). The ultrasound time of 2 minutes, the ultrasound initial temperature of $50{ }^{\circ} \mathrm{C}$ and the malaxation time of 43.23 minutes were found to be the predicted optimal conditions of the UAE process of extra virgin olive oil. Under these optimized experimental condition, the predicted values for olive oil yield and acidity were $8.42 \%$ and $0.283 \mathrm{~g}$ oleic acid/100 g olive oil, respectively, whose desirability values were equal to 0.914 .

To verify the reliability of the models under the optimal conditions, experiments were performed. The experimental values for the acidity $8.31 \%$ and the yield were $0.31 \mathrm{~g}$ oleic acid $/ 100 \mathrm{~g}$ olive oil. These results were in good agreement with the predicted values under the optimal working condition. Table 6 shows the error rates between the experimental and predicted values which are smaller than $10 \%$. Therefore, the acidity value of olive oil and yield for any combination of ultrasound time, ultrasound temperature and malaxation time could be accurately predicted by the regression models obtained by RSM.

\section{CONCLUSIONS}

Worldwide olive oil consumption has risen recently due to its beneficial effects on human health. To meet the growing needs of consumers and to produce high-quality olive oil, new extraction methods are needed. The effects of different extraction parameters (ultrasound time, initial ultrasound temperature and malaxation time) on the antioxidant activity, yield, nutritional and sensory qualities of olive oil were investigated in this study. Concerning the free acidity, peroxide value, K232 and K270, all the oils obtained with or without ultrasound could be classified as "Extra Virgin Olive Oil" according to European norms. It can be concluded that under the tested conditions sonication had a physical effect on the olive pastes causing minimal changes in their chemical properties. The results showed that applying sonication prior to malaxation at a high temperature is an effective technique for extra virgin olive oil extraction and the benefit of this technique includes higher extraction yield and lower extraction time with no negative effect on quality or antioxidant activity of virgin olive oil. In this study, 
TABLE 6. Predicted Values and Experimental Values

\begin{tabular}{|c|c|c|c|c|c|c|c|c|c|}
\hline \multicolumn{3}{|c|}{ Extraction conditions } & \multirow[b]{2}{*}{ Desirablity } & \multirow[b]{2}{*}{$\begin{array}{l}\text { Predicted } \\
\text { Yield (\%) }\end{array}$} & \multirow[b]{2}{*}{$\begin{array}{c}\text { Experimental } \\
\text { Yield (\%) }\end{array}$} & \multirow[b]{2}{*}{$\begin{array}{l}\text { Error } \\
\text { rate } \\
(\%)\end{array}$} & \multirow[b]{2}{*}{$\begin{array}{l}\text { Predicted } \\
\text { AV (g oleic } \\
\text { acid/ } 100 \mathrm{~g} \\
\text { oil) }\end{array}$} & \multirow[b]{2}{*}{$\begin{array}{c}\text { Experimental } \\
\text { AV (g oleic } \\
\text { acid/ } 100 \mathrm{~g} \\
\text { oil) }\end{array}$} & \multirow[b]{2}{*}{$\begin{array}{l}\text { Error } \\
\text { rate }(\%)\end{array}$} \\
\hline $\begin{array}{l}\text { Ultrasound } \\
\text { time (min.) }\end{array}$ & $\begin{array}{l}\text { Ultrasound } \\
\text { initial } \\
\text { temperature } \\
\left({ }^{\circ} \mathrm{C}\right)\end{array}$ & $\begin{array}{l}\text { Malaxation } \\
\text { time (min.) }\end{array}$ & & & & & & & \\
\hline 2 & 50 & 43 & 0.914 & 8.42 & 8.31 & 1.29 & 0.283 & 0.31 & -8.71 \\
\hline 3 & 50 & 45 & 0.872 & 8.42 & 8.45 & -0.39 & 0.302 & 0.33 & -8.48 \\
\hline 2 & 43 & 45 & 0.824 & 8.42 & 7.87 & 6.95 & 0.306 & 0.29 & 5.52 \\
\hline 2 & 50 & 50 & 0.796 & 9.04 & 8.80 & 2.70 & 0.351 & 0.38 & -7.63 \\
\hline 2 & 30 & 46 & 0.785 & 6.98 & 7.12 & -1.97 & 0.248 & 0.23 & 7.83 \\
\hline 5 & 50 & 31 & 0.743 & 7.31 & 7.41 & -1.38 & 0.346 & 0.33 & 3.56 \\
\hline 8 & 50 & 22 & 0.701 & 7.15 & 7.20 & -0.71 & 0.431 & 0.41 & 5.12 \\
\hline
\end{tabular}

no significant differences between the experimental values and predicted values confirmed the second order polynomial models and optimal extraction conditions.

\section{ACKNOWLEDGEMENT}

The authors are grateful to Aydar Olive Company (Akhisar, Manisa) for providing olive samples and Manisa Celal Bayar University is gratefully acknowledged for financial support (project: BAP-2015-105)

\section{REFERENCES}

Abenoza M, Benito M, Saldaña G, Álvarez I, Raso J, SánchezGimeno AC. 2013. Effects of Pulsed Electric Field on Yield Extraction and Quality of Olive Oil. Food Bioprocess Technol. 6, 1367-1373. http://dx.doi.org/10.1007/s11947-012-0817-6

Achat S, Tomao V, Madani K. Chibane M, Elmaataoui M, Dangles O, Chemat F. 2012. Direct enrichment of olive oil in oleuropein by ultrasound-assisted maceration at laboratory and pilot plant scale. Ultrason. Sonochem. 19, 777-786. http://dx.doi.org/10.1016/j.ultsonch.2011.12.006

Aguilera MP, Beltran G, Sanchez-Villasclaras S, Uceda M, Jimenez A. 2010. Kneading olive paste from unripe "Picual" fruits: I. Effect on oil process yield. J. Food Eng. 97, 533-538. http://dx.doi.org/10.1016/j.jfoodeng.2009.11.013

Angerosa F, Mostallino R, Basti C, Vito R. 2001. Influence of malaxation temperature and time on the quality of virgin olive oils. Food Chem. 72, 19-28. http://dx.doi.org/10.1016/ S0308-8146(00)00194-1

Bejaoui MA, Beltran G, Aguilera MP, Jimenez A. 2016. Continuous conditioning of olive paste by high power ultrasounds: Response surface methodology to predict temperature and its effect on oil yield and virgin olive oil characteristics. LWT - Food Sci. Technol. 69, 175-184. http://dx.doi.org/10.1016/j.lwt.2016.01.048

Bejaoui MA, Beltrán G, Sánchez-Ortiz A, Sánchez S, Jiménez A. 2015. Continuous high power ultrasound treatment before malaxation, a laboratory scale approach: Effect on virgin olive oil quality criteria and yield. Eur. J. Lipid Sci. Technol. http://dx.doi.org/10.1002/ejlt.201500020

Ben Brahim S, Marrakchi F, Gargouri B, Bouaziz M. 2015. Optimization of malaxing conditions using $\mathrm{CaCO} 3$ as a coadjuvant: A method to increase yield and quality of extra virgin olive oil cv. Chemlali. LWT - Food Sci. Technol. 63, 243-252. http://dx.doi.org/10.1016/j.lwt.2015.03.013

Boskou D. 2007. Olive oil, Chemistry and Technology, World review of nutrition and dietetics. http://dx.doi. org/10.1159/000097916
Clodoveo ML. 2012. Malaxation: Influence on virgin olive oil quality. Past, present and future - An overview. Trends Food Sci. Technol. 25, 13-23. http://dx.doi.org/10.1016/j. tifs.2011.11.004

Clodoveo ML, Durante V, La Notte D. 2013a. Working towards the development of innovative ultrasound equipment for the extraction of virgin olive oil. Ultrason. Sonochem. 20, 1261-1270. http://dx.doi.org/10.1016/j. ultsonch.2013.02.001

Clodoveo ML, Durante V, La Notte D, Punzi R, Gambacorta G. 2013b. Ultrasound-assisted extraction of virgin olive oil to improve the process efficiency. Eur. J. Lipid Sci. Technol. 115, 1062-1069. http://dx.doi.org/10.1002/ejlt.201200426

Clodoveo ML, Hachicha Hbaieb R. 2013. Beyond the traditional virgin olive oil extraction systems: Searching innovative and sustainable plant engineering solutions. Food Res. Int. 54, 1926-1933. http://dx.doi.org/10.1016/j. foodres.2013.06.014

De Fernandez MDLA, Soto Vargas VC, Silva MF. 2014. Phenolic Compounds and Antioxidant Capacity of Monovarietal Olive Oils Produced in Argentina. J. Am. Oil Chem. Soc. 91, 2021-2033. http://dx.doi.org/10.1007/ s11746-014-2558-3

Di Giovacchino L, Costantini N, Ferrante ML, Serraiocco A. 2002. Influence of malaxation time of olive paste on oil extraction yields and chemical and organoleptic characteristics of virgin olive oil obtained by a centrifugal decanter at water saving. Grasas Aceites 53, 179-186. http://dx.doi. org/10.3989/gya.2002.v53.i2.302

Espínola F, Moya M, Fernández DG, Castro E. 2009. Improved extraction of virgin olive oil using calcium carbonate as coadjuvant extractant. J. Food Eng. 92, 112-118. http:// dx.doi.org/10.1016/j.jfoodeng.2008.10.038

European Union Commission Regulation, 1991. (EEC) No 2568/91. Official European Commission Journal, Brussels.

Fiori F, Di Lecce G, Boselli E, Pieralisi G, Frega NG. 2014. Effects of olive paste fast preheating on the quality of extra virgin olive oil during storage. LWT - Food Sci. Technol. 58, 511-518. http://dx.doi.org/10.1016/j,lwt.2014.03.021

Franco MN, Galeano-Díaz T, López Ó, Fernández-Bolaños JG, Sánchez J, De Miguel C, Gil MV, Martín-Vertedor D. 2014. Phenolic compounds and antioxidant capacity of virgin olive oil. Food Chem. 163, 289-298. http://dx.doi. org/10.1016/j.foodchem.2014.04.091

Gandul-Rojas B, Mínguez-Mosquera MI. 1996. Chlorophyll and Carotenoid Composition in Virgin Olive Oils from Various Spanish Olive Varieties. J. Sci. Food A gric. 72, 31-39. https:// doi.org/10.1002/(SICI)1097-0010(199609)72:1<31::AIDJSFA619>3.0.CO;2-5

Gómez-Rico A, Inarejos-García AM, Salvador MD, Fregapane G. 2009. Effect of malaxation conditions on phenol and volatile profiles in olive paste and the corresponding virgin olive oils (Olea europaea L. Cv. cornicabra). J. Agric. Food Chem. 57, 3587-3595. http://dx.doi.org/10.1021/jf803505w 
Inarejos-García AM, Gómez-Rico A, Salvador MD, Fregapane G. 2009. Influence of malaxation conditions on virgin olive oil yield, overall quality and composition. Eur. Food Res. Technol. 228, 671-677. http://dx.doi.org/doi:10.1007/ s00217-008-0977-9

International Olive Oil Council, 2003. IOOC Trade Standard Applying to Olive Oils and Olive - Pomace Oils.COI/T.15. NC No 3/Rev. 1, 2003.

Jiménez A, Beltrán G, Uceda M. 2007. High-power ultrasound in olive paste pretreatment. Effect on process yield and virgin olive oil characteristics. Ultrason. Sonochem. 14, 725-731. http://dx.doi.org/10.1016/j.ultsonch.2006.12.006

Jiménez Márquez A, Beltrán Maza G, Uceda Ojeda M, Paz Aguilera Herrera M. 2006. Empleo de ultrasonidos de potencia en le proceso de elaboracion del aceite de oliva virgen. Resultados a nivel de planta de laboratorio. IrUse of high power ultrasounds in virgin olive oil extraction process. Results at laboratory scale. Grasas Aceites 57, 253-259. https://doi.org/10.3989/gya.2006.v57.i3.46

Kadam SU, Tiwari BK, Alvarez C, O'Donnell CP. 2015. Ultrasound applications for the extraction, identification and delivery of food proteins and bioactive peptides. Trends Food Sci. Technol. 46, 60-67. http://dx.doi. org/10.1016/j.tifs.2015.07.012

Montedoro G, Servili M. 1992. Simple and hydrolyzable phenolic compounds in virgin olive oil. 1. Their extraction, separation, and quantitative and semiquantitative evaluation by HPLC. J. Agric. Food Chem. 40, 1571-1576. http:// dx.doi.org/10.1021/jf00021a019

Puértolas E, Martínez de Marañón I. 2015. Olive oil pilotproduction assisted by pulsed electric field: Impact on extraction yield, chemical parameters and sensory properties. Food Chem. 167, 497-502. http://dx.doi.org/10.1016/j. foodchem.2014.07.029

Samaram S, Mirhosseini H, Tan CP, Ghazali HM, Bordbar S, Serjouie A. 2015. Optimisation of ultrasound-assisted extraction of oil from papaya seed by response surface methodology: Oil recovery, radical scavenging antioxidant activity, and oxidation stability. Food Chem. 172, 7-17. http://dx.doi.org/10.1016/j.foodchem.2014.08.068

Sevim D, Tuncay O, Koseoglu O. 2013. The Effect of Olive Leaf Addition on Antioxidant Content and Antioxidant Activity of "Memecik" Olive Oils at Two Maturity Stages. J. Am. Oil Chem. Soc. 90, 1359-1369. http://dx.doi. org/10.1007/s11746-013-2282-4

Stefanoudaki E, Koutsaftakis A, Harwood JL. 2011. Influence of malaxation conditions on characteristic qualities of olive oil. Food Chem. 127, 1481-1486. http://dx.doi. org/10.1016/j.foodchem.2011.01.120

Taticchi A, Esposto S, Veneziani G, Urbani S, Selvaggini R, Servili M. 2013. The influence of the malaxation temperature on the activity of polyphenoloxidase and peroxidase and on the phenolic composition of virgin olive oil. Food Chem. 136, 975-983. http://dx.doi.org/10.1016/j.foodchem.2012.08.071 